\title{
ANALYSIS OF LEECH THERAPY EFFECTS IN PATIENTS WITH CHRONIC APICAL PERIODONTITIS
}

\author{
Abdullaeva Al ${ }^{\otimes}$, Prityko AG, Voronin PA, Mikhailova EG
}

Pirogov Russian National Research Medical University, Moscow, Russia

\begin{abstract}
Chronic apical periodontitis (CAP) is characterized by tissue inflammation around the tooth tip. Unstable outcomes of current treatments against CAP dictate the need for novel therapeutic techniques and medications. The aim of this study was to analyzed the effects of hirudotherapy on the treatment course in patients with CAP. Forty-one study participants aged 25 to 40 years were divided into the main group (20 patients) and the control group (21 patients). Pain level and the gingival index (Gl) were measured in all study participants. During the first visit, pain scores did not differ significantly between the control (5.81 \pm 0.65$)$ and the main (5.75 \pm 0.92$)$ groups. During the second visit, pain was almost unnoticeable in the main group patients $(1.05 \pm 0.34)$, whereas pain scores were higher in the control group ( $4.10 \pm 0.7)$. Our findings suggest a positive effect of hirudotherapy used in combination with standard treatment regimens.
\end{abstract}

Keywords: hirudotherapy, chronic apical periodontitis, inflammation, pain

Author contribution: Abdullaeva Al — literature and experimental data analysis, experimental data analysis; Prityko AG — experimental data analysis, experimenta data analysis; Voronin PA — statistical analysis, manuscript revision; Mikhailova EG — statistical analysis, manuscript revision.

Compliance with ethical standards: the study was approved by the Ethics Committee of Pirogov Russian National Research Medical University (Protocol № 947 dated February 4, 2019). Informed consent was obtained from all study participants.

$\square$ Correspondence should be addressed: Aitan I. Abdullaeva

Ostrovityanova, 1, Moscow, 117997; aitanka@list.ru

Received: 01.05.2020 Accepted: 15.05.2020 Published online: 18.05.2020

DOI: $10.24075 /$ brsmu.2020.028

\section{АНАЛИЗ РЕЗУЛЬТАТА ПРИМЕНЕНИЯ МЕТОДА ГИРУДОТЕРАПИИ ПРИ ЛЕЧЕНИИ ХРОНИЧЕСКОГО АПИКАЛЬНОГО ПЕРИОДОНТИТА}

\author{
А. И. Абдуллаева $\bowtie$, А. Г. Притыко, П. А. Воронин, Е. Г. Михайлова \\ Российский национальный исследовательский медицинский университет имени Н. И. Пирогова, Москва, Россия
}

\begin{abstract}
Для хронического апикального периодонтита (ХАП) характерно воспаление тканей, окружающих верхушку корня зуба. Отсутствие стабильности результатов стандартного лечения объясняет поиск новых лекарственных средств и методов лечения данного заболевания. Целью исследования было проанализировать влияние гирудотерапии в лечении ХАП при динамическом наблюдении с использованием клинических методов исследования. Пациенты в возрасте от 25 до 40 лет (всего 41 человек) были разделены на основную группу (20 человек) и группу сравнения (21 человек). У всех участников исследования определяли показатели выраженности постоянных болевых ощущений и десневого индекса Gl. B первое посещение показатели выраженности болевых ощущений в группе сравнения $(5,81 \pm 0,65)$ и основной группе $(5,75 \pm 0,92)$ сильно не различались. K третьему посещению у пациентов основной группы боль почти отсутствовала (1,05 \pm 0,34), а в группе сравнения показатели были выше $(4,10 \pm 0,7)$. Результаты клинических исследований указывают на положительное влияние гирудотерапии в составе комплексного лечения.
\end{abstract}

Ключевые слова: гирудотерапия, хронический апикальный периодонтит, воспаление, боль

Вклад авторов: А. И. Абдуллаева - анализ литературы и полученных данных, написание статьи; А. Г. Притыко - анализ полученных данных, участие в написании статьи; П. А. Воронин - обработка полученных данных, статистическая обработка данных, редактирование рукописи; Е. Г. Михайлова обработка полученных данных, редактирование рукописи.

Соблюдение этических стандартов: исследование одобрено этическим комитетом РНИМУ имени Н. И. Пирогова (протокол № 947 от 04 февраля 2019 г.). Все пациенты подписали добровольное информированное согласие на участие в исследовании.

$\bowtie$ Для корреспонденции: Айтан Измировна Абдуллаева ул. Островитянова, д. 1, г. Москва, 117997; aitanka@list.ru Статья получена: 01.05.2020 Статья принята к печати: 15.05.2020 Опубликована онлайн: 18.05.2020 DOI: $10.24075 /$ vrgmu.2020.028

The prevalence of chronic apical periodontitis (CAP) in dentistry patients over 18 years of age is $95-100 \%$ [1]. Unstable outcomes of current treatments against CAP dictate the need for novel therapeutic techniques and medications. Hirudotherapy, i.e. application of medicinal leeches Hirudo medicinalis, dates back centuries [2]. It has proved to be effective in treating a number of conditions, including battle wounds [3]. Among absolute contraindications for hirudotherapy are malignancies, blood clotting disorders, thrombocytopenia, and intolerance of leech saliva components [4, 5]. At present, leeches are used to relieve pain and treat asthma, high blood pressure, migraine, phlebitis, varicose veins, and dental diseases [2, 6-7]. In most cases, leech therapy has positive outcomes; however, adverse events are possible. When the leech bites, it injects into the wound a complex mixture of bioactive ingredients, including hirudin [8]. Hirudin is a polypeptide that irreversibly binds to thrombin; the resulting complex blocks conversion of fibrinogen into fibrin
[9-10]. This improves microcirculation in tissues, produces anti-inflammatory and analgesic effects, and stimulates tissue regeneration [11]. Leech therapy has been approved by the Russian Ministry of Healthcare; there is a pharmacopeial monograph (PM-42-702-97) containing a list of quality control guidelines for this treatment type. The literature on the efficacy of hirodutherapy in periodontitis is scarce, and the question remains whether it is feasible for treating CAP [12].

The aim of this study was to investigate the effect of hirudotherapy on the pace of clinical improvement in patients receiving a combination therapy for CAP.

\section{METHODS}

The study was carried out in 41 patients with exacerbated CAP undergoing treatment at the facilities of Voyno-Yasenetsky Research and Practical Center for Specialized Medical Care 
Table 1. Demographics of the participants

\begin{tabular}{|l|c|c|}
\hline & Main group $(n=20)$ & Control group $(n=21)$ \\
\hline Sex, $\mathrm{m} / \mathrm{f}$ & $8 / 12$ & $9 / 12$ \\
\hline Mean age (years), $\mathrm{M} \pm m$ & $31.4 \pm 0.4$ & $30.2 \pm 0.3$ \\
\hline
\end{tabular}

for Children in January through March 2020. Of all study participants, 17 were men and 24 were women aged 25 to 40 years. The mean age of the participants was $29.1 \pm 1.7$ years in the female group and $34.6 \pm 1.4$ year in the male group, respectively. The study included patients with CAP who required endodontic retreatment, had no dental fistulas and were 25 to 40 years old. The following exclusion criteria were applied: decompensated comorbidities, a flare-up of a chronic comorbidity, inflammatory periodontal disease, pregnancy, HIV, blood clotting disorders, cancer, refusal to participate. Chronic apical periodontitis (ICD code: K04.5) was diagnosed based on CT findings (GENORAY; South Korea).

The patients were divided into 2 groups. The main group consisted of 20 patients who received standard treatment for CAP complemented by hirudotherapy. The mean age in the main group was $30.0 \pm 1.0$ years for women and $33.5 \pm 1.3$ years for men. The control group included 21 patients who received only standard treatment. The mean age in this group was $31.5 \pm 1.2$ years for women and $28.4 \pm 1.4$ years for men (Table 1). The groups did not differ in terms of age and sex.

Endodontic treatment was carried out following the guidelines proposed by the European Society of Endodontology in 1994 (tooth preparation; rubber dam isolation; access cavity preparation; determination of the working length; cleaning, shaping and filling of the root canal system). Dental materials and medications were the same for all study participants. In the main group, endodontic procedures were followed by leech therapy. Briefly, a medicinal leech was applied to the alveolar mucosa over the apical aspect of the causative root using an aspiration technique; the leech was allowed to feed for 20-30 min until it detached. The leeches used in the study were purchased at the HirudoCenter (Russia; Certificate of Conformity ROSS RU.AD77.H00310, valid from January 29, 2018 through January 28, 2021). The main group received 3 courses of leech therapy: on days 1, 4 and 7 of treatment, as recommended by the hirudotherapy guidelines [13].

The efficacy of the applied treatment was assessed based on the level of pain and the gingival index (Gl) developed by Löe и Silness (1963); patient dynamics were compared between the groups [8]. Pain was measured on a visual analog scale (VAS): 0 - no pain; 1-3 - mild pain; $4-$ moderate pain; 5-6 - severe pain; 7-9 - very severe pain; 10 - unbearable pain. Gl is traditionally used to evaluate the periodontium for the clinical signs of gingival inflammation, which include redness, edema and bleeding on probing (in our case, at the site of the examined tooth). Gl scores were interpreted as follows: 0 - no signs of inflammation; 1 - a slight change in color, mild edema, no bleeding on probing (mild inflammation); 2 - redness, edema, bleeding on probing (moderate inflammation); 3 - marked redness, edema, ulceration, a tendency to spontaneous bleeding (severe inflammation) [8].

Statistical analysis was done in SPSS 21 (IBM SPSS Statistics; USA). Differences were considered significant at $p \leq 0.05(95 \%)$

\section{RESULTS}

On day 1 , pain scores did not differ significantly between the groups. In the main group, pain was less pronounced during the second visit and almost unnoticeable during the third visit; the main group patients reported the analgesic effect of hirudotherapy (Table 2). On day 4 of treatment (the second visit), pain scores in the control group were also lower than at the onset of treatment; during the third visit, however, pain scores in the control group were much higher than in the main group. An increase in pain scores observed in the control group on day 7 was linked to the normal body reaction to a medical intervention.

In both groups, Gl scores were decreasing steadily over the entire course of treatment. However, on days 4 and $7 \mathrm{Gl}$ was lower in the main group than in the control group. Hirodutherapy reduced edema and redness and had an analgesic effect.

Thus, the analysis of clinical symptoms suggests a positive effect of leech therapy on the outcome of combination therapy in patients with CAP.

\section{DISCUSSION}

This study demonstrates a positive effect of hirudotherapy used in combination with standard treatment regimens in patients with CAP and confirms its analgesic and anti-inflammatory effects previously reported by Russian researchers. Another study consistent with our findings has shown that hirudotherapy reduces endogenous toxic effects in the affected dentoalveolar region in patients with periodontal tissue destruction [14]. Our study suggests that hirudotherapy is also effective in reducing periodontal inflammation. During the third visit, no hyperemia was observed in the main group, whereas in the control group its level remained almost unchanged throughout the entire course of treatment. A dissertation written in 2003 is also consistent with our findings and points to the fact that hirudotherapy used in combination with standard treatment regimens can relieve pain, reduce edema, inflammation and the duration of therapy [15]. In our experiment, additional parameters were used, including pain scores on the 10-point scale and the gingival index.

Table 2. Dynamics of the gingival index (GI) and pain scores in patients with CAP in the main and control groups

\begin{tabular}{|l|c|c|c|c|c|c|}
\hline & \multicolumn{2}{|c|}{ Day 1} & \multicolumn{2}{c|}{ Day 4 Day 7} \\
\hline Parameters & Main group & Control group & Main group & Control group & Main group & Control group \\
\hline $\begin{array}{l}\text { Pain, points } \\
(\mathrm{M} \pm m)\end{array}$ & $5.75 \pm 0.92$ & $5.81 \pm 0.65$ & $2.5 \pm 0.54$ & $3.29 \pm 0.68$ & $1.05 \pm 0.34^{*}$ & $4.1 \pm 0.75$ \\
\hline $\begin{array}{l}\text { Gingival index Gl, points } \\
(\mathrm{M} \pm m)\end{array}$ & $1.88 \pm 0.06$ & $1.92 \pm 0.05$ & $1.13 \pm 0.10$ & $1.45 \pm 0.13$ & $0.38 \pm 0.06^{*}$ & $1.13 \pm 0.06$ \\
\hline
\end{tabular}

Note: * $-p<0.05$; comparison with the control group 
Based on the pain, edema and hyperemia scores on days 1,4 , and 7 of treatment, we conclude that these parameters were lower in the patients who received hirudotherapy. In the main group, leech secretions expediated the resolution of inflammation and had a pronounced decongestive and painrelieving effect, resulting in clinical improvement. No adverse effects of hirudotherapy were observed.

\section{References}

1. Berezin KA, Grekov AH, Zaripova YeM, Starceva EYu. Statisticheskie aspekty izuchenija rasprostranennosti hronicheskogo apikal'nogo periodontita u vzroslogo naselenija. Sovremennye problemy nauki i obrazovanija. 2015; 2 (1). URL: http://www.science-education.ru/ ry/article/view?id=19306 (data obrashhenija: 8.05.2020). Russian.

2. Kunal J, Aarti G, Ridhi N, Sunanda D. Hirudotherapy in Medicine and Dentistry. J Clin Diagn Res. 2015; 9 (12): ZE05-ZE07.

3. Sashkina TI, Abdullaeva Al, Runova GS, Saldusova IV, Zajchenko OV Fashutdinov DK, et al. Hirudotherapy in treatment of chronic generalised periodontitis. Vestnik RGMU. 2019; 4: 79-83.

4. Spear M. Medicinal Leech Therapy: Friend or Foe. Plast Surg Nurs. 2016; 36 (3): 121-5

5. Liu C, Barkley TW Jr. Medicinal leech therapy: New life for an ancient treatment. Nursing. 2015; 45 (11): 25-30.

6. Fedotova YuM, Kostjukova Yul. Girudoterapija: teorija i praktika. Nauchnoe obozrenie. Medicinskie nauki. 2017; 2: 22-25. Russian.

7. Kulbida R, Mathes A, Loeser J. Beneficial effects of hirudotherapy in a chronic case of complex regional pain syndrome. J Integr Med. 2019; 17 (5): 383-6.

8. Şenel E, Taylan Özkan A, Mumcuoglu KY. Scientometric analysis

\section{CONCLUSIONS}

Our findings suggest that hirudotherapy can be recommended as a complement to conventional treatment of CAP and used in the clinical setting for relieving pain and reducing inflammation. Further research is needed to study the long-term effects of leech therapy using modern diagnostic modalities, including radiography.

\section{Литература}

1. Березин К. А., Греков А. Х., Зарипова Э. М., Старцева Е. Ю. Статистические аспекты изучения распространенности хронического апикального периодонтита у взрослого населения. Современные проблемы науки и образования. 2015; 2 (1). URL: http://www.science-education.ru/ry/article/ view?id=19306 (дата обращения: 8.05.2020).

2. Kunal J, Aarti G, Ridhi N, Sunanda D. Hirudotherapy in Medicine and Dentistry. J Clin Diagn Res. 2015; 9 (12): ZE05-ZE07.

3. Сашкина Т. И., Абдуллаева А. И., Рунова Г. С., Салдусова И. В., Зайченко О. В., Фасхутдинов Д. К. и др. Гирудотерапия в лечении хронического генерализованного пародонтита. Вестник РГМУ. 2019; 4: 83-86.

4. Spear M. Medicinal Leech Therapy: Friend or Foe. Plast Surg Nurs. 2016; 36 (3): 121-5

5. Liu C, Barkley TW Jr. Medicinal leech therapy: New life for an ancient treatment. Nursing. 2015; 45 (11): 25-30.

6. Федотова Ю. М., Костюкова Ю. И. Гирудотерапия: теория и практика. Научное обозрение. Медицинские науки. 2017; 2: 22-25.

7. Kulbida R, Mathes A, Loeser J. Beneficial effects of hirudotherapy in a chronic case of complex regional pain syndrome. J Integr Med. 2019; 17 (5): 383-6.

8. Senel E, Taylan Özkan A, Mumcuoglu KY. Scientometric analysis of medicinal leech therapy. J Ayurveda Integr Med. 2019: S09759476(18)30349-8. DOI: 10.1016/j.jaim.2018.11.006.

9. Liu C, Barkley TW Jr. Medicinal leech therapy: New life for an ancient treatment. Nursing. 2015; 45 (11): 25-30.

10. Sig AK, Guney M, Uskudar Guclu A, Ozmen E. Medicinal leech therapy-an overall perspective. Integr Med Res. 2017; 6 (4): 337-43.

11. Kim KS, Sim HS, Shin JH, Hwang JH, Lee SY. The Relationship between Explanation and Patient Compliance in Hirudotherapy. Arch Craniofac Surg. 2017; 18 (3): 179-85.

12. Kruer RM, Barton CA, Roberti G, Gillbert B, McMillian WD. Antimicrobial prophylaxis during Hirudo medicinalis therapy: a multicenter study. J Reconstr Microsurg. 2015; 31 (3): 205-9.

13. Использование метода гирудотерапии в практическом здравоохранении. Методические рекомендации № 2002/78 (утв. Минздравом РФ 15.07.2002). Доступно по ссылке: https://www.lawmix.ru/medlaw/26582.

14. Орлова Е. Е. Гирудотерапия деструктивных форм верхушечного периодонтита [диссертация]. М., 2003.

15. Денискина Е. В. Клинико-лабораторное обоснование гирудотерапии в комплексном лечении хронического периодонтита [диссертация]. М., 2003. 